donts, or possibly to a combination of these factors. That they are not environmental is shown by the presence of all these different species in the different environments of deposition which existed in other areas.

Abundance-analysis of any particular species of conodont tends to be four-fold. First, tho abundance of the species in terms of the amount of rock processed (which is a reflexion of the effect of ecology and sedimentology on the original population); second, the relative abundance of a species in terms of the total fauna; third, the abund. ance of a species in terms of the other species of the genus; and fourth, the abundance of a specios in terms of its morphologieal group, either blade or platform. The last three analyses show the relationship which exists between different species, but the conclusions from such studies as to the original relationship between the speries will always be controlled by considerations such as postdepositional sorting, of which these studins take little account.

For correlation purposes it is important to distinguish real differences between conodont faunas, which are due to differences in stratigraphical distribution of species, and apparent differences, which are none the less real, and which reflect the environment in which the conodontbearing "animal" lived. Comparative studies must be made over a wide region in order to appreciato the true significance and importance of new conodont faunas.

R. J. Alditid:

R. L. Austrin

S. HUSRI

Department, of (xeology,

University of Southampton.

Reccived May 2; revised May :7, 1968.

Rhodes, F.H. T., Austin, R. L., and Druce, E. C., Bull. Rrit. Mus. Nat. Hist. (Geol.) Suppl. No. 4 (in the press, 1968).

Neaverson, E., Proc. Lipool. Geol. Soc., 15, 179 (1930).

${ }^{3}$ Neaverson, E., in Geology Around the University Towns: Liverpool, (ceol. Assoc. Guide No. 6, 23 (1965).

${ }^{4}$ Brandon, A., thesis, University of Southampton (1968).

${ }^{5}$ Meischner, D., C.R. Cong. Avanc. Etude Stratigr. Cart. (in the press).

${ }^{\circ}$ Varker, W. J., Palaeontology, 10, 124 (1967).

'Austin, R. L., and Rhodes, F. H. T., Palaeontology (in the press).

"Higgins, A. C., Geol. Mag., 98, 210 (1961).

\section{Copepod Remains in the Sediments of Lake Balaton, Hungary}

Two remains of copepods, representing most parts of the animals, have been recovered in a Late Pleistocene sample (vegetation phase $1 b$ ) from a core of the sediments of Lake Balaton in Hungary. One of these remains is of a diaptomid, apparently moulting (Fig. 1), and the other is of a cyclopoid copepod. With the exception of various parts of these bodies found in the superficial lake sediments and

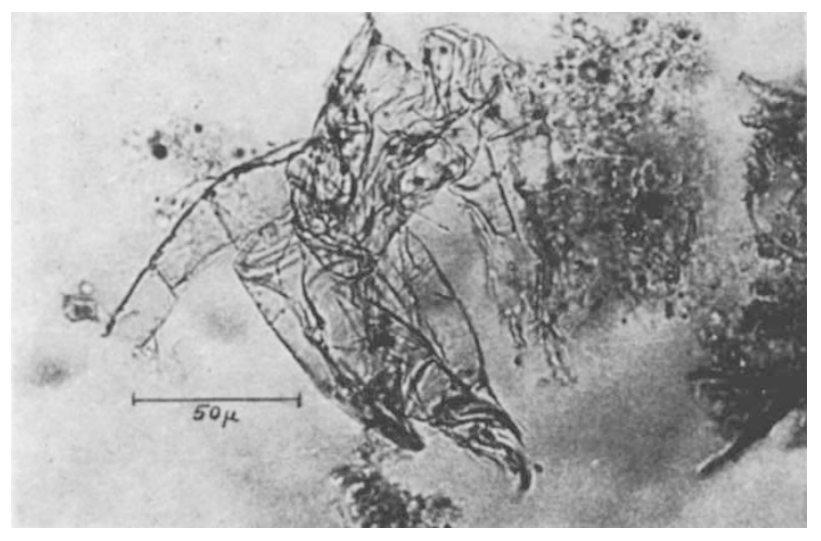

Fig. I. Remains of a specimen of Diaptomidae thought to be moulting. of spermatophores found in bogs, there are very fow well documented remains of the animals themselves, and none is from the Pleistocenex. The good preservation of the copepod chitin in this case can probably be attributed to some favourable environmental conditions in the relevant layers of sediments in Lake Balaton.

Biology Research Institute of the

Olga Sebtestyén

Hungarian Academy of Sciences,

Tihany, Hungary.

Received April 26, 1968.

' Frey, D. G., Arch. Hydrobiol. Beiheft. Ergebn. Limnol., 2, 57 (1964),

\section{"Primary" Leads}

ThF idea that the lead in many large ore bodies originates from a uniform, deep-scated, possibly upper-mantle. source region ${ }^{1}$ has proved of great value, particularly in the recognition and interpretation of the systematics of "anomalous" ("multi-stage") lead systems. When these so-called "single-stage" or "primary" lead deposits came to be examinod in greater detail ${ }^{2}$, however, the situation turned out to be not quite so simple; it led Kanascwich and Farquhar", for example, to conclude that " $n \circ$ infallible geologic criteria have been found for independently distinguishing ordinary or single-stage leads from those which were produced in two or more distinct leaduranium-thorium systems". Other indications of the need for re-cxamination of current ideas about the "primary lead" system are the many geophysical data which suggest lateral inhomogeneities in the upper mantle 4 , supported by isotopic data which suggest long-term inhomogeneities in its $\mathrm{U} / \mathrm{Pb}$ ratio ${ }^{5}$, and the contention by Hobbs and his co-authors ${ }^{8}$ that the seemingly stratiform nature of the deposit at Broken Hill, NSW, may be not quite so directly the result of sedimentary processes as has been asserted'.

I have therefore re-examined the positions relative to the average growth-curve $e^{3}$ of a number of "stratiform" leads. These are predominantly gas-source results from the University of British Columbia, normalized according to the "loop-closure" technique ${ }^{2}$. All solid-source results obtained before the very recent development of the doublespike procedure 8,8 are liable to excessive fractionation, the amount of which is difficult to judge from published information; the resulting possible scatter makes them inapplicable to this study except in the broadest of terms. The somewhat striking conclusion is that these "stratiform orebodies" as dofined by Russell and Stanton ${ }^{10}$ can be subdivided on the basis of their apparent "model ages" and " $\mu$-values" $\left({ }^{238} \mathrm{U} /{ }^{204} \mathrm{~Pb}\right.$ extrapolated to present day value), into three distinct classes.

These are summarized in Table 1 , in which are listed mean values for ${ }^{206} \mathrm{~Pb} /{ }^{204} \mathrm{~Pb},{ }^{207} \mathrm{~Pb} /{ }^{204} \mathrm{~Pb}$, and the derived values of "model age" and "apparent $\mu$-value" based on an assumed "primary" model. For the present treatment it is not necessary to assume that the last two quantities are related to any real system; the error limits, calculated as standard deviations of the mean of a set of normalized results from a single occurrence, can be shown to be similar in most cases to independent estimates of the experimental error. On this basis both coherence between members of a class, and the experimental significance of the differences between classes, can be statistically demonstrated.

This clear isotopic classification is reflected by differences in geological environment. The first and most striking observation is that the orebodies in high-grade metamorphic terrains (class $3 B$ ) all fall remarkably close to the average growth-curve; if there had originally been signs of volcanic activity it has since been obliterated; the mode ages scem closely related to the apparent 